\title{
THE SECONDARY BACTERIAL CO-INFECTIONS ACCOMPANIED SHEEP FASCIOLIASIS AT TAIF, KSA
}

\author{
SHERIFA MOSTAFAMOHAMED SABRA \\ "Microbiology Dept., Science Collage, Taif University, KSA / Animal Health Research Institute, Dokki, Giza, Egypt) \\ Corresponding Author: Dr. Sherifa Mostafa Mohamed Sabra, \\ E.mail: atheer1800@yahoo.com
}

\section{ABSTRACT}

Received at: 11/3/2013

Accepted: 21/3/2013
The study was carried out at Taif slaughtered house of small ruminants, KSA. It was done in period time of (2010-2012). The animals of study were sheep for the purpose of meat production in an attempt to measure the economic losses due to parasite and microbes co-infections leading to meat condemnations. Specimens were collected as liver lesions, gall bladder and flukes. Sheep were slaughtered and examined (No.=29.100), infected livers by Fascioliasis were (940) 3.2\% from totally slaughtered sheep, and they were differentiated into acute cases (629) $66.9 \%$ and chronic cases (311) 33.1\%. The bacterial isolates recovered from all samples were 7 types, Staph. spp., Strept. spp. E. coli,Proteus spp., Klebsiella spp., Clostridium perfringens and Clostridium novyi. In animals with acute infections the 7 types of bacteria were recovered from liver lesionsin the percentages of $15.3,8.9,7.6,3.3,2.7,13.8$ and $2.2 \%$, gall bladder 1.2, 1.0, 15.5, $12.9,11.1,22.9$ and $8.7 \%$, flukes $1.4,1.1,14.1,13.5,10.7,22.4$ and $8.3 \%$ respectively. The total isolates were 53.9, 73.2 and $71.6 \%$ from liver lesions, gall bladder and flukes.Incidence of bacterial types were isolated from chronic cases from liver lesions 17.4, 10.3, 11.6, 9.6, 6.8, 17.7 and 5.8\% respectively. The isolates were isolated from gall bladder 1.0, 0.6, 15.7, 9.0, 7.4, 19.3 and 7.4\%, flukes were $0.6,1.0,12.9,7.4,8.4,18.3$ and $7.0 \%$. So the total isolates $79.1,60.5$ and $55.6 \%$ were from liver lesions, gall bladder and flukes.

Key words: Spp., Staph., Strept.,E. coli., Proteus, Klebsiella, Clostridium perfringens, Clostridium novyi.

\section{INTRODUCTION}

Liver is considered as an important organ for animal health production, carrying many metabolic activities of the body and reproduction. Liver infection was an important disease that affects all kinds of meat producing animals, this lead to great losses to live-stock production and national income due to condemnation of great numbers of livers in the slaughter houses (Foster and Woods, 1970; Tomate, 1973). It caused by liver fluke species, Fasciola hepatica and Fasciola gigantica, It is a zoonotic disease of great veterinary importance and considerable public health significance (Hcrschcla, 1998). Fasciola hepatica has a cosmopolitan distribution but the distribution of Fasciola gigantica is limited in Asia and Africa (Torgerson and Claxton, 1999). The definitive host range was very broad and includes many herbivorous mammals (Spithill et al., 1999). Fascioliasis was an important helminthes disease belongs to the plant borne trematodezoonoses. Fasciola hepatica was overlap in many areas of Africa and Asia (Mas-Coma et al., 2005). Fascioliasis of domestic animals were widely distributed, well- known parasitic disease, with worldwide distribution, an important emerging food born trematode infection of increasing concern (Massoud, 1993; Mas-Coma and Bargues, 1997; Rokni et al., 2002; Mas-Coma et al., 2005). Mixed infection with Fasciola hepatica and Fasciola gigantica were a rule (Hosseini et al., 2004; Ashrafi et al., 2006), both species had been reported from sheep (Hosseini et al., 2010; Meshgi et al., 2008). The prevalence of Fascioliasis in young and adult sheep were $12.7 \%$ and $28.7 \%$. The disease was caused by digenean of the genus Fasciola commonly referred to as liver flukes. The two species most commonly implicated as the etiological agents of Fascioliasis are Fasciola hepatica and Fasciola gigantica. The distributions of both species overlap in many areas of Africa and Asia (Khaled et al., 2010). The presence of Fasciola spp. 2.5\% of sheep (Hosseini et al., 2010). Infections had been associated with two types of liver disease in domestic animals: acute or sub-acute necrotic disease due to juvenile flukes; and chronic fibrotic disease due to adult flukes. Penetration of the liver capsule by immature flukes generally does not cause much damage, but their subsequent migration through the liver parenchyma may cause significant necrosis (liver rot). 
Mass migration of juveniles may produce extensive traumatic tissue damage, coagulative necrosis, and can be fatal. Acute infections in sheep can also be complicated by secondary bacterial co-infection causing Clostridial necrotic hepatitis ('black disease') (Dubinský, 1993; Behm and Sangster, 1999). Clinical presentation was divided into 4 types Acute Type I Fascioliasis: infectious dose was more than 5000 ingested meta-cercariae. Sheep suddenly die without any previous clinical signs. Ascites, abdominal hemorrhage, icterus, pallor of membranes, weakness may be observed in sheep.Acute Type II Fascioliasis: infectious dose was 1000-5000 ingested metacercariae. Sheep die but briefly show pallor, loss of condition and ascites.Sub-acute Fascioliasis: infectious dose was 800-1000 ingested metacercariae. Sheep are lethargic, anemic and may die, weight loss was a dominant feature. Chronic Fascioliasis: infectious dose was 200-800 ingested meta-cercariae. Asymptomatic or gradual development of bottle jaw and ascites (ventral edema), emaciation, weight loss (Dubinský, 1993; Behm and Sangster, 1999). The effects of liver flukes were referred to as Fascioliasis, and include anemia, weight loss and submandibular edema; diarrhea was only an occasional consequence. Little damage was done by juveniles penetrating the intestinal wall and the capsule surrounding the liver but much necrosis results from migration of flukes through the liver parenchyma. During this time, they feed on liver cells and blood. Anemia sometimes resulted from heavy infections. Worms in bile ducts caused inflammation and edema, which in turn stimulate production of fibrous tissue in the walls of these ducts. Thus thickened, the ducts can handle less bile and were less responsive to needs of the liver. Back pressure caused atrophy of liver parenchyma, with concomitant cirrhosis and possibly jaundice. In heavy infections the gall bladder was damaged, and walls of the bile ducts were eroded completely. The damaged liver tissue may become infected by the bacteria Clostridium spp. which will release toxins into the bloodstream resulting in black disease, death follows quickly. Clostridium novyi was common in the environment, black disease was found wherever populations of liver flukes and sheep overlap (Merck, 2010). Chronic infections by the long-lived adults feeding on the lining of the bile ducts may result in progressive loss of condition, biliary epithelial hyperplasia, duct fibrosis, biliary obstruction and cholangitis, jaundice, and eventually a fibrotic hardened liver. Secondary co-infections and expensive treatments.Chronic infections can lead to hepatic lesions, fibrosis, chronic inflammation of the bile ducts. Bacterial cholangitis was a clinically defined syndrome caused by the regurgitation of infected bile into the circulation (Hcrschcla, 1998). This was confirmed in the early chronic phase, where a bacterial co-infection of the common bile duct was detected at 8weeks post infection in Fasciola hepatica (Foster, 1984). Liver of the infected ruminant was damaged, partially or completely condemned and the sub-clinical and chronic disease usually resulted in decreased production of meat, milk, wool, and secondary bacterial co-infections problems (Black and Froyd, 1972; Coop and Sykes, 1977; Hope et al., 1977; Daryani et al., 2006). The presence of fluke infection bacteria was thought to flourish due to changes in the biliary environment (Foster, 1984). Fasciola played an important role in the microbial invasion of the infected animals either by transportation or by depressing the vital resistance of the host. Besides, infected liver constitute a good media for bacterial multiplication, transportation of micro-organisms with the parasites occurs during the different stages of its life cycle either outside or inside the animal body. Anaerobic necrotic lesions of the liver produced by immature flukes occasionally provides a suitable environment for the germination of spores of Clostridium novyi type B bacteria in the liver (Eguale and Abie, 2003). The causes of biliary obstruction that predispose to bacterial cholangitis were myriad (Dobrucali et al., 2004). The adult flukes inhabited the bile duct and gall bladder of liver. Inside their host, the liver flukes caused severe damages may lead to the death of the animals (Anosike et al., 2005). The bacteriological bile culture revealed E. coli $50 \%$, Klebsiella pneumonia $30 \%$, Pseudomonas $8 \%$, Proteus 5\% in Egypt (Samia et al., 2008). Apparently infected sheep $30.4 \%$ with acute suppurative hepatitis while $69.6 \%$ appeared to be infected with chronic hepatitis, $51.4 \%$ anaerobic and $48.6 \%$ facultative anaerobic. In case of chronic hepatitis were Clostridium perfringens $74.3 \%$ and $E$. coli $48.6 \%$. The histo-pathological of acute hepatitis revealed hepatic necrosis and degeneration with presence of multiple variable sized abscesses in the hepatic parenchyma. While the chronic hepatitis revealed increased fibrous connective tissue proliferation in the portal triads, around small and large bile ducts and in the Glasson's capsule. The biliary epithelium were hyperplastic with formation of large numbers of newly formed bile ductules and presence of mature Fasciola worm within the lumen of the main bile ducts (Sohair and Eman, 2009). A serious consequence of the liver damage caused by Fascioliasis was that latent Clostridium novyi spores can be activated by the low oxygen conditions in the damaged tracts the parasite forms in the liver; this can lead to "black disease", or immune-mediated hemolytic anemia (IMHA) leading to haemoglobinuria by Clostridium novyi type D. The bacteria will release toxins into the blood stream resulting in black disease in sheep, which is known as infectious necrotic hepatitis. The primary infection was intestinal and transferred by the fecal-oral route. Spores of Clostridium novyi escape from the gut and lodge in the liver where they remain dormant until some injury creates anaerobic conditions for them to germinate causing local necrosis and widespread damage to the micro vascular system resulting in subcutaneous bleeding and blackening of the skin, 
hence the common name, black disease results from interaction of bacteria Clostridium novyi and fluke Fasciola hepatica, as other enterotoxaemia, leads to sudden death. The post/mortem (P/M) lesions were peritoneal and thoracic cavities contains a great quantity of fluids, as did pericardial sac. Liver was swollen with sometimes peri hepatitis, great number of necrotic foci, which extend deeply in the organ. Hepatic lymph nodes were enlarged. The gall bladder was full, subcutaneous tissues were full of cyanotic venous blood, may darken the hide (Jensen and Brinton, 1982). Sub-clinical and chronic Fascioliasis resulted in decreased production of meat, milk and wool (Black and Froyd, 1972; Coop and Sykes, 1977; Hope et al., 1977; Daryani et al., 2006). The nutritional and health value of the animal and losses of body weight were reported (Shar-Fisher and Say, 1989). Liver flukes caused severe damages leaded to the death of the animals (Anosike et al., 2005). Among the animal diseases that hinder the animal health were parasitic infections that had great economic impact, especially in developing countries. Fascioliasis was one of the most common economically important parasitic diseases of domestic livestock, in sheep. (Khaled et al., 2010).Infection of domestic ruminants with Fasciola hepatica (temperate liver fluke) and Fasciola gigantica (tropical liver fluke) caused significant economic losses. Worldwide losses in animal productivity due to Fascioliasis were conservatively estimated at over US $\$ 3.2$ billion/annum. The losses were at slaughter houses, the infected livers going for condemnation, partially or completely (Black and Froyd, 1972; Coop and Sykes, 1977; Hope et al., 1977; Daryani et al., 2006), such infection brought decreased in meat production and subsequent economic losses, leading to poor carcass quality and losses (Shar-Fisher and Say, 1989). Chronic Fascioliasis caused significant economic losses to many animal industries through mortality, reduced meat, milk and wool production, condemned livers, secondary co-infections. Importance of Fascioliasis in economic losses caused by condemnation of livers at slaughtered houses and production losses especially due to reduce weight gain (Eguale and Abie, 2003). The estimated annual losses to live stock due to Fascioliasis all over the world was more than 2.000 million dollars (Mungube et al., 2006). The major aim of the present research was study the incidence of sheep Fascioliasis at slaughtered house at Taif, KSA. Followed up the acute and chronic hepatitis infections by isolation and identification of causative micro-organisms associated with Fascioliasis. Looking the relation between Fascioliasis and predisposing factors facilitate the microbial hepatitis co-infections. Investigated the economic losses through the condemnation of livers and carcasses of sheep due to complication of Fascioliasis and co-infections was emphasized.

\section{MATERIALS and METHODS}

Field Study: This study was carried out on specimens from Taif slaughtered house of small ruminants, KSA. It was done in a two year period (2010-2012). The animals under study were slaughtered sheep for the purpose of meat production Infected liver specimens were collected after Post/Mortem (P/M) inspections, then grading by dates of collection, hepatitis infection type and location. During the 2-years period mentioned for study, the total of examined slaughtered sheep were (No.=29.100), the number of infected liver by Fascioliasis were 940, after the routine P/M inspection of livers and gall bladders were carried out for Fasciolaspp. Livers were inspected by making multiple deep incisions of the lobes and making a deep cut with a number of small sub cuts. Gall bladders were opened using a sterile knife and thoroughly investigated for the presence of Fasciola spp., the livers were differentiated according to the signs as acute cases (No.=629) and chronic cases (No.=311). The specimens were Liver, gall bladder and fluke. The data were managed from slaughtered house for each sheep.

\section{Parasitical Pattern:}

Identification of Fascioliasis: Investigation and identification of Fasciola were done according to their distinct morphology, this study was a retrospective from slaughtered house survey which used its data for period time (Jan. 2010 - Dec. 2012G), and involved (No.=29.100) sheep were slaughtered at Taif small ruminants slaughtered house, KSA, Each specimen was identified (Urquhart et al., 1996).

\section{Bacterial Pattern:}

- Specimen Collection: The specimens were collected from slaughtered house at Taif, KSA. The infected livers were collected, isolation and identification of micro-organisms were screened from liver lesions, gall bladders and flukes. Grossly the whole infected liver were $($ No.=940), as (No.=629) were acute while, (No.=311) chronic hepatitis. Infected liver specimens were collected at the time of slaughter separately in sterile containers, under sterile condition; the specimens were transferred directly to the laboratory for bacterial examination.

- Aerobic Isolation and Identification: A loopful from each specimen was streaked onto the nutrient agar, MacConkey agar and blood agar plates, and then incubated aerobically at $37^{\circ} \mathrm{C}$ for $24 \mathrm{hrs}$. Isolated colonies of various types (based on morphological appearance) were picked from plates and sub cultured on blood agar plates. Bacterial isolates were identified based on morphology, culture and biochemical analysis (Quinn et al., 2002). 
- Anaerobic Isolation and Identification: A loopful from each specimen was inoculated into two tubes of freshly prepared cooked meat broth, one of them was heated at $80^{\circ} \mathrm{C}$ for 10 minutes, to eliminate non spore forming organisms while the other tube was left without heating, both tubes were incubated anaerobically at $37^{\circ} \mathrm{C}$ for $48 \mathrm{hrs}$. A loopful from each heated tube were streaked onto blood agar plate for isolation of spore forming anaerobes while, loopful from non-heated tubes were streaked onto neomycin blood agar and brain-heart infusion blood agar (BHIBA) plates for isolation of Clostridium perfringens and non-spore forming anaerobes. All plates were examined after anaerobic incubation for
2-3 days and each colony type was sub-cultured for identification, Clostridium perfringens isolates were typed using the intra-dermal inoculation test in Albino Guinea pigs (Sterne and Batty, 1975; Konoman et al., 1992).

Data Analysis: The data which were recorded during the study period were entered into Microsoft excel sheet. Data were summarized and analyzed using SPSS version 16 computer and Epi Info version 6 statistical software (Coulombier et al., 2001), and for further compared using Chi-square test at critical probability of $\mathrm{p}<0.05$.

\section{RESULTS}

Table 1:Incidence of Fascioliasis and Hepatic infection types among total slaughtered sheep

\begin{tabular}{lcccc}
\hline \multirow{2}{*}{ year } & Slaughtered No. & Fascioliasis (\%) & \multicolumn{2}{c}{ Hepatic Infection Types No. 940 } \\
\cline { 4 - 5 } $\mathbf{2 0 1 0}$ & 7.200 & $2.9 \%$ & $68.6 \%$ & Chronic (\%) \\
\hline $\mathbf{2 0 1 1}$ & 10.100 & $3.4 \%$ & $66.2 \%$ & $31.4 \%$ \\
\hline $\mathbf{2 0 1 2}$ & 11.800 & $3.3 \%$ & $66.7 \%$ & $33.8 \%$ \\
\hline Total & $\mathbf{2 9 . 1 0 0}$ & $\mathbf{9 4 0}(\mathbf{3 . 2 \%})$ & $\mathbf{6 2 9}(\mathbf{6 6 . 9 \%})$ & $\mathbf{3 1 1 ( 3 3 . 1 \% )}$ \\
\hline
\end{tabular}

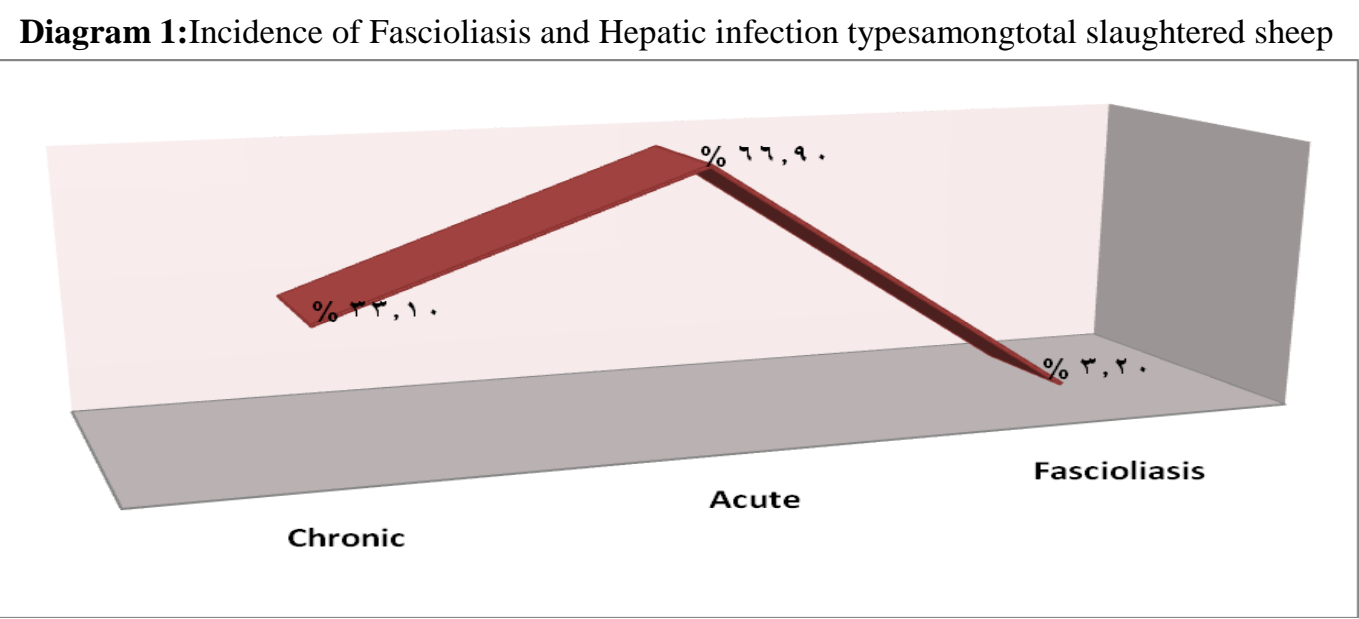

The Total slaughtered sheep at Taif, KSA, during (2010-2011) were 29.100, table (1) and diagram (1) show incidence of Fascioliasis as 3.2\% were in 2010, 2011 and 2012 as 2.9, 3.4 and $3.3 \%$. The distribution of Fascioliasis were in acute $66.9 \%$ as $2010(68.6 \%), 2011(66.2 \%)$ and $2012(66.7)$, chronic was $33.1 \%$ as 2010 (31.4\%), $2011(33.8 \%)$ and $201233.3 \%)$.

Table 2: Incidence ofbacterial types isolated from acute casesamong livers

\begin{tabular}{lccc}
\hline \multirow{2}{*}{ Bacterial Types } & \multicolumn{3}{c}{ Acute Cases No. 629 } \\
\cline { 2 - 4 } & $\begin{array}{c}\text { Liver lesions } \\
(\boldsymbol{\%})\end{array}$ & $\begin{array}{c}\text { Gall Bladder } \\
(\boldsymbol{\%})\end{array}$ & $\begin{array}{c}\text { Flukes } \\
(\boldsymbol{\%})\end{array}$ \\
\hline Staph. Spp. & $15.3 \%$ & $1.2 \%$ & $1.4 \%$ \\
\hline Strept. Spp. & $8.9 \%$ & $1.0 \%$ & $1.1 \%$ \\
\hline E. coli & $7.6 \%$ & $15.5 \%$ & $14.1 \%$ \\
\hline Proteus Spp. & $3.3 \%$ & $12.9 \%$ & $13.5 \%$ \\
\hline Klebsiella Spp. & $2.7 \%$ & $11.1 \%$ & $10.7 \%$ \\
\hline Clostridium perfringens & $13.8 \%$ & $22.9 \%$ & $22.4 \%$ \\
\hline Clostridium novyi & $2.2 \%$ & $8.7 \%$ & $8.3 \%$ \\
\hline Total & $\mathbf{5 3 . 9 \%}$ & $\mathbf{7 3 . 2 \%}$ & $\mathbf{7 1 . 6 \%}$ \\
\hline
\end{tabular}


Diagram 2: Incidence of bacterial types isolated from acute casesamonglivers

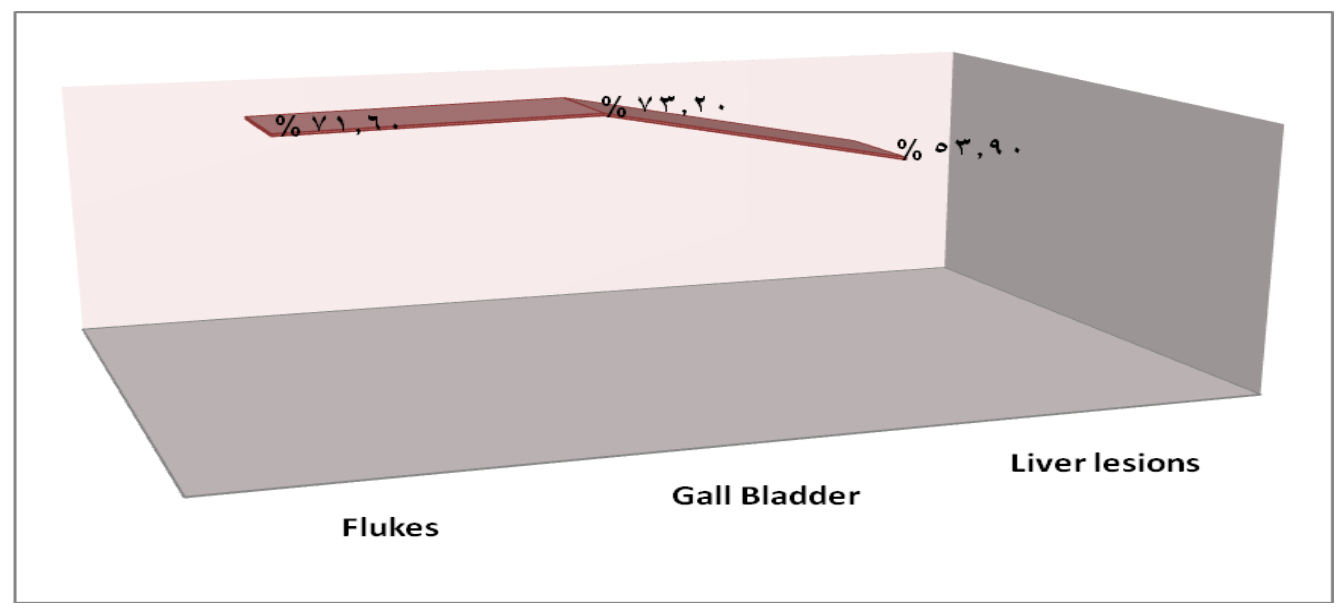

Table (2) and diagram (2) show the bacterial isolates were 7 types, Staph. spp., Strept. spp. E. coli, Proteus spp., Klebsiella spp., Clostridium perfringens and Clostridium novyi. Incidence of bacterial types isolated from acute cases of slaughtered sheep were in liver lesions 15.3, 8.9, 7.6, 3.3, 2.7, 13.8 and 2.2\% respectively. The isolates were from gall bladder 1.2, 1.0, 15.5, 12.9, 11.1, 22.9 and 8.7\% respectively. Finally from flukes were 1.4, 1.1, $14.1,13.5,10.7,22.4$ and $8.3 \%$. The total isolates 53.9, 73.2 and 71.6\% were from liver lesions, gall bladder and flukes.

Table 3: Incidence of bacterial types isolated from chronic cases amonglivers

\begin{tabular}{lccc}
\hline \multirow{2}{*}{ Bacterial Types } & \multicolumn{3}{c}{ Chronic Cases No. 311 } \\
\cline { 2 - 4 } & $\begin{array}{c}\text { Liver Lesions } \\
(\boldsymbol{\%})\end{array}$ & $\begin{array}{c}\text { Gall Bladder } \\
(\boldsymbol{\%})\end{array}$ & $\begin{array}{c}\text { Flukes } \\
(\boldsymbol{\%})\end{array}$ \\
\hline Staph. Spp. & $17.4 \%$ & $1.0 \%$ & $0.6 \%$ \\
\hline Strept. Spp. & $10.3 \%$ & $0.6 \%$ & $1.0 \%$ \\
\hline E. coli & $11.6 \%$ & $15.7 \%$ & $12.9 \%$ \\
\hline Proteus Spp. & $9.6 \%$ & $9.0 \%$ & $7.4 \%$ \\
\hline Klebsiella Spp. & $6.8 \%$ & $7.4 \%$ & $8.4 \%$ \\
\hline Clostridium perfringens & $17.7 \%$ & $19.3 \%$ & $18.3 \%$ \\
\hline Clostridium novyi & $5.8 \%$ & $7.4 \%$ & $7.0 \%$ \\
\hline Total (\%) & $\mathbf{7 9 . 1 \%}$ & $\mathbf{6 0 . 5 \%}$ & $\mathbf{5 5 . 6 \%}$ \\
\hline
\end{tabular}

Diagram 3: Incidence of bacterial types isolated from chronic cases amonglivers (3)

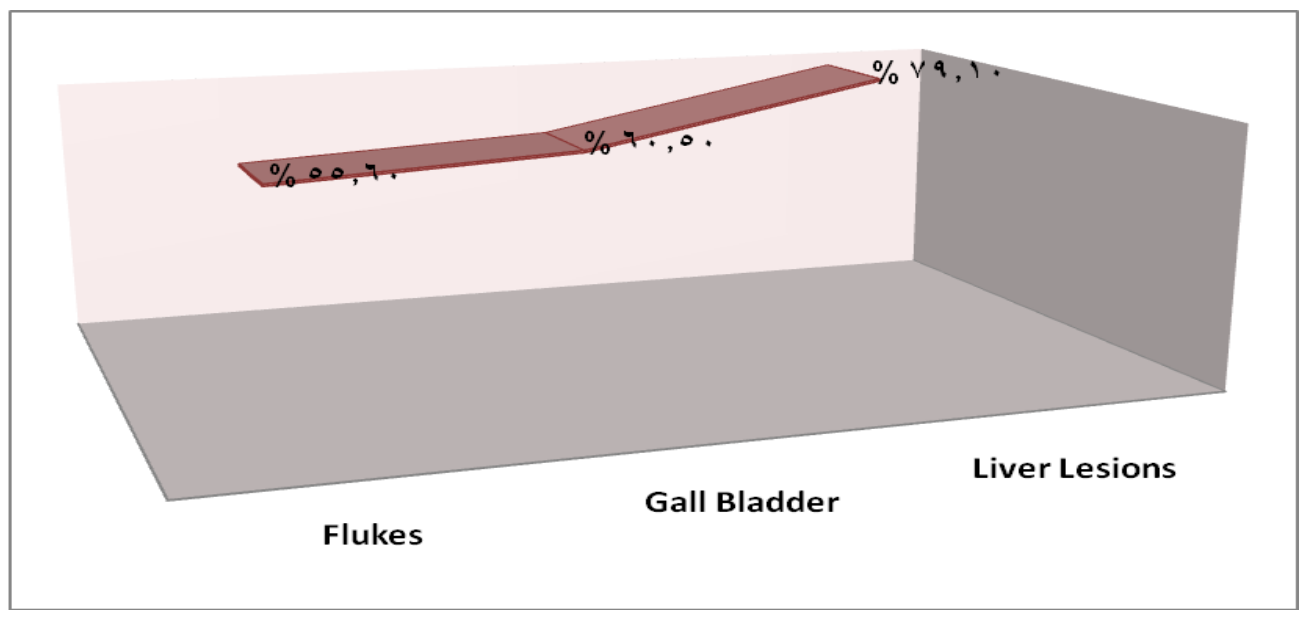

Table (3) and diagram (3) show incidence of bacterial types isolated from chronic cases were liver lesions 17.4, 10.3, 11.6, 9.6, 6.8, 17.7 and 5.8\% respectively. The isolates were from gall bladder 1.0, 0.6, 15.7, 9.0, 7.4, 19.3 and $7.4 \%$ respectively. Finally from flukes were $0.6,1.0,12.9,7.4,8.4,18.3$ and $7.0 \%$. So the total isolates were79.1, 60.5 and 55.6\% from liver lesions, gall bladder and flukes. 


\section{DISCUSSION}

Incidence of total Fascioliasis was 3.2\%, distributed in 2010, 2011 and 2012 as 2.9\%, 3.4\% and 3.3\% respectively. Fascioliasis was in acute infection $66.9 \%$ as in $2010(68.6 \%), 2011(66.2 \%)$ and 2012 $(66.7 \%)$, chronic infection was $33.1 \%$ as in 2010 (31.4\%), 2011 (33.8\%) and 2012 33.3\%). Fasciola hepatica was a concern but the distributions of both Spp. overlap in many areas of Africa and Asia (MasComa et al., 2005). Mixed infection with $F$. hepatica and F. gigantica (Hosseini et al., 2004; Ashrafi et al., 2006), both spp. had been reported from sheep (Hosseini et al., 2010; Meshgi et al., 2008). The prevalence of Fascioliasis in young and adult sheep were $12.7 \%$ and $28.7 \%$, and caused by digenean of the genus Fasciola commonly referred to as liver flukes. The two Spp. most commonly implicated as the etiological agents of Fascioliasis are $F$. hepatica and $F$. gigantica. In Europe, America, only Fasciola hepatica is a concern, but the distributions of both species overlap in many areas of Africa and Asia (Khaled et al., 2010). The presence of Fasciola spp. $2.5 \%$ of sheep (Hosseini et al., 2010).

Fluke bacteria co-infection was thought to flourish due to changes in the biliary environment (Foster, 1984). Fasciola played an important role in the microbial invasion of the infected animals either by transportation or by depressing the vital resistance of the host. Besides, infected liver constitute a good media for bacterial multiplication, transportation of micro-organisms with the parasites occurs during the different stages of its life cycle either outside or inside the animal body. Anaerobic necrotic lesions of the liver produced by immature flukes occasionally provides a suitable environment for the germination of spores of Clostridium novyi type B bacteria in the liver (Eguale and Abie, 2003). The causes of biliary obstruction that predispose to bacterial cholangitis were myriad (Dobrucali et al., 2004). The adult flukes inhabited bile duct and gall bladder of liver in these animals. Inside their host, the liver flukes caused severe damages which may leaded to the death of the animals (Anosike et al., 2005).

The bacterial isolates were 7 types, Staph. spp., Strept. spp. E. coli, Proteus spp., Klebsiella spp., Clostridium perfringens and Clostridium novyi. Incidence of bacterial types isolated from acute cases of slaughtered sheep were in liver lesions 15.3, 8.9, 7.6, 3.3, 2.7, 13.8 and $2.2 \%$ respectively, from gall bladder $1.2,1.0,15.5,12.9,11.1,22.9$ and $8.7 \%$ respectively, from flukes were $1.4,1.1,14.1,13.5$, 10.7, 22.4 and $8.3 \%$. The total isolates were 53.9, 73.2 and $71.6 \%$ from liver lesions, gall bladders and flukes.The bacteria would release toxins into the blood stream resulting in black disease in sheep. Incidence of bacterial types isolated from chronic cases of slaughtered sheep were liver lesions 17.4,
10.3, 11.6, 9.6, 6.8, 17.7 and 5.8\% respectively. The isolates were from gall bladders 1.0, 0.6, 15.7, 9.0, 7.4, 19.3 and 7.4\%, from flukes were 0.6, 1.0, 12.9, $7.4,8.4,18.3$ and $7.0 \%$. So the total isolates 79.1 , 60.5 and $55.6 \%$ were from liver lesions, gall bladders and flukes respectively. Infected sheep, bacteriological bile culture revealed E. coli 50\%, Klebsiella pneumonia 30\%, Proteus 5\% (Samia et al., 2008). Apparently infected were $30.4 \%$ with acute suppurative hepatitis while $69.6 \%$ appeared to be infected with chronic hepatitis, $51.4 \%$ anaerobic and $48.6 \%$ facultative anaerobic, were recovered from acute suppurative hepatitis specimens. In chronic hepatitis Clostridium perfringens was $74.3 \%$, E. coli 48.6\% (Sohair and Eman, 2009). Fascioliasis was that latent Clostridium novyi type $\mathrm{B}$ spores can be activated by the low oxygen conditions in damaged tracts the parasite forms in the liver; bacteria released toxins into the blood stream resulting in black disease in sheep, (Jensen and Brinton, 1982).

The losses on field in sheep were sudden deaths, reduction of weight gain and wool production (Sinclair, 1962; Roseby, 1070), which causes great losses in livestock production (Mas-Coma and Bargues, 1997; Mas-Coma et al., 2005). The subclinical and chronic disease usually resulted in decreased production of meat, milk and wool (Black and Froyd, 1972; Coop and Sykes, 1977; Hope et al., 1977; Shar-Fisher and Say, 1989; Daryani et al., 2006). Liver flukes caused severe damages which leads to the death of the animals (Anosike et al., 2005). Parasitic infections that had great economic impact, especially in developing countries. Fascioliasis was one of the most common economically important parasitic diseases of domestic livestock (Khaled et al., 2010). Fascioliasis caused significant economic losses, estimated at over US\$3.2 billion/annum. The losses at slaughter houses, liver of the infected ruminant was damaged partially or completely condemned (Black and Froyd, 1972; Coop and Sykes, 1977; Hope et al., 1977; Daryani et al., 2006), which decreased in meat production and subsequent economic losses, leading to poor carcass quality and losses (Shar-Fisher and Say, 1989). The estimated annual losses to live stock due to Fascioliasis all over the world was more than 2.000 million dollars (Mungube et al., 2006). Chronic Fascioliasis caused significant economic losses through mortality, reduced meat, milk and wool production, condemned livers and secondary bacterial co-infections. Condemnation of livers at slaughtered houses and production losses especially due to reduced weight gain (Eguale and Abie, 2003).

\section{Conclusions:}

This study shows that the bacterial co-infection with Fasciola was a common occurrence; it concluded that livers of sheep showed a very high proportion. Fascioliasis isincriminated to act as an aid to bacterial co-infections which lower the hepatic viability.Livers 
of slaughtered sheep were considered as hazardous source of different mixed infections, parasite spp. and bacterial spp. Fascioliasis was an important helminthes disease and one of the major obstacles for livestock causing remarkable direct and indirect losses. The liver bacterial co-infections were the causes for that increasing the condemnation of livers at slaughtered houses, black disease was lead to condemnation of whole carcasses. Severe losses of meat affected the coefficient of meat. The Veterinary preventive methods must be concerning the treatment of infected sheep and cutting the life cycle of Fasciola.

\section{Acknowledgments:}

Thankful was directed for Veterinary Doctors at slaughtered house at Taif, KSA for their help in inspection for livers Fascioliasis, bacterial coinfections and providing the specimens for parasitological and microbiological investigations. The grateful also passed to Laboratory Department staff for their special work on the specimens.

\section{REFERENCES}

Anosike, J.; Opara, M.; Okoli, C. and Okoli, I. (2005): Prevalence of parasitic helminthes among ruminants in Etiti area of Imo State, Nigeria. Animal prod. Res. Advances, 1:13-19.

Ashrafi, K.; Valero, M.; Panova, M.; Periago, M.; Massoud, J. and Mas-Coma, S. (2006): Phenotypic analysis of adult of F. hepatica, F. gigantica and intermediate forms from the endemic region of Gilan, Iran. Parasitol. Int., 55: 249-260.

Behm, C. and Sangster, N. (1999): Pathology, pathophysiology and clinical aspects. In: Dalton, J. P. (Ed.), Fascioliasis. CAB Int. Publishing, Wallingford, Pp: 185-224.

Black, N. and Froyd, G. (1972): The possible influence of liver fluke infestation on milk quality. Vet. Rec., 90:71-72.

Coop, R. and Sykes, A. (1977): F. hepatica: The effect of sub-clinical infection on food intake and efficiency of food utilization. Para., 75:xxxvixxxvii.

Coulombier, D.; Fagan, R.; Hathcock, L. and Smith, C. (2001): Epi Info 6 Version 6.04. A Word Processing, Database and Statistical Program for Public Health. Centers for Disease Control and Prevention, Atlanta, Delaware, USA.

Daryani, A.; Alaei, R.; Arab, R.; Sharif, M. and Dehghanand, H. (2006): Prevalence of Liver Fluke Infections in Slaughtered Animals in Ardabil Province, Northwestern Iran. J. Animal and Vet. Advances, 5: 408-411.

Dobrucali, A.; Yigitbasi, R. and Erzin (2004): F. hepatica infestation as a very rare cause of extra-hepatic cholestasis. World J. Gastrocnrcrol., 10: 3076-7.
Dubinský, P. (1993): Trematódy a trematodózy. In: Jurášek, V., Dubinský, P. a kolektív, Vet. Para.Prírodaa.s., Bratislava, 18:158-187.

Eguale, T. and Abie, G. (2003): Some clinicopathological observations of sheep artificially infected with F. gigentica. Bull. Anim.Health Prod. Africa., 51: 113-115.

Foster, I. (1984): Bacterial infection of the common bile duct in chronic Fascioliasis in the rat. J. Camp Pathol., 94: 175-81.

Foster, L. and Woods, W. (1970): Influence of liver abscesses on animal performance. J. Anim. Sci., 31: 241-245

Hcrschcla, A. (1998): Bacterial and parasitic cholangitis. Mayo Clin Proc., 73: 473-478.

Henok, M. and Mekonnen, A. (2011): Study on The Prevalence and Risk Factors of Fascioliasis in Small Ruminants In And Around Hirna Town, Ethiopia, Global Vet., 7: 497-501.

Hope, M.; Strickland, K.; Conway, A. and Crowe, P. (1977): Production effects of liver fluke in cattle. I. The effects of infection on live weight gain, feed intake and food conversion efficiency in beef cattle. British Vet. J., 133: 145-159.

Hosseini, S.; Jlochani, M.; Bahonar, A. and Eslami, A. (2010): Cattle Fascioliasis in Gilan province, Iran. Int. J. Vet. Res., 4:57-60.

Hosseini, S.; Vaezi, V.; Jafari, G.; Rezaei, A. and Carami, G. (2004): Epidemiological study of Fascioliasis in Kermanshah province. J. Fac. Vet. Med., University of Tehran. 59: 201-206.

Jensen, R. and Brinton, L. (1982): Diseases of Sheep Philadelphia, Lea \&FebigerPp: 210-213.

Khaled, S.; Desoukey, M.; Elsiefy, M. and Elbahy, N. (2010): An Abattoir Study on the Prevalence of Some Gastrointestinal Helminths of differences. Sheep in Gharbia Governorate, Egypt. Global Vet., 5: 84-87.

Konoman, E.; Paul, C.; Schreckenberger, S.; Allen, W. and Washington, C. (1992): Color Atlas And Textbook Of Diagnostic Microbiology. $4^{\text {th }}$ ed. J. B. Lippincott Company Philadelphia.

Mas-Coma, S.; Bargues, M. and Valero, M. (2005): Fascioliasis and other plant-borne trematode zoonoses. Int. J. Para., 35: 1255-1278.

Mas-Coma, S. and Bargues, M. (1997): Human liver flukes: a review. Res. Rev. Para., 57: 145-218.

Massoud, J. (1993): Present status of human Fascioliasis in Iran. In: Food-borne trematodes. WHO Manual, Manila, Mimeogr. Rep WHO Manual, Manila, Mimeogr. Rep Sch/SG/93 w, Pp: 19.

Merck Veterinary Manual (2010): Infectious Necrotic Hepatitis.

Meshgi, B.; Eslami, A. and Hemmatzadeh, F. (2008): Determination of somatic and excretory antigens of F. hepatica and F. gigantica using SDS-PAG. Iranian J. Vet. Res., 9: 77-80.

Mungube, E.; Bauni, S.; Tenhagen, B.; Wamae, L.; Nginyi, J. and Mugambi, J. (2006): The 
prevalence and economic significance of $\mathrm{F}$. gigantica and F. hepatica in slaughtered animals in the semi-arid coastal, Kenya. Tropical Anim. Health and Pro., 38:475-483.

Quinn, P.; Markey, B.; Carter, M.; Donnelly, W.; Leonarrd, F. and Magnia, D. (2002): Veterinary Microbiology and Microbial Diseases. $1^{\text {st }}$ ed. Published, Blackwell Science Ltd.

Rokni, M.; Massoud, J.; Neill, S.; Parkinson, M. and Dalton, J. (2002): Diagnosis of human Fascioliasis in the Gilan province of northern Iran, application of cathepsin ELISA Diag. Microbiol. Infect. Dis., 44: 175-179.

Roseby, F. (1970): The effect of Fascioliasis on the wool production of merino sheep. Aust. Vet. J. 46: 361-365.

Samia, W.; Maysa, S. and Fatern, R. (2008): Fascioliasis and Bacterobilia in Experimentally and Naturally Infected Animals, Para. United J., I: 123-128.

Shar-Fisher, M. and Say, R. (1989): Manual of tropical veterinary parasitology. CAB Inter., Wallingford, U.K.
Sinclair, K. (1962): Observations on the clinical pathology of ovine Fascioliasis. Brit. Vet. J.118: 37-53.

Sohair, B. and Eman, N. (2009): Histo-pathological and bacteriological studies on livers affected with Fascioliasis in cattle. Egypt. J. Comp. Path. \& Clinic. Path. 22: 19-43.

Spithill, T.; Smooker, P. and Comeman, D. (1999): F. gigantica: Epidemiology, control, immunology and molecular biology in Dalton, JP: Fascioliasis. Wallingford. Dxon, UK: CABI Pub, 465-525.

Sterne, D.; and Batty, I. (1975): Pathogenic clostridium. $1^{\text {st }}$ ed., Butte-worth, London, UK.

Tomate, H. (1973): High Incidence of ruminal lesions and liver abscess prefecture. Tohoku, J. Agra. Res., 23:184-199.

Torgerson, P. and Claxton, J. (1999): Epidemiology and control. In: Dalton, JP (Ed.), Fascioliasis. ( $1^{\text {st }}$ Edn. $)$, CAB International Publication. UK. Pp: 113-149.

Urquhart, G.; Armour, J.; Duncan, L.; Dunn, A. and Jennings, F. (1996): Veterinary parasitology, $2^{\text {nd }}$ edition, University of Oxford, Long man scientific and technical press, UK, Pp:100-109.

\footnotetext{
العدوي الثانوية البكتيرية المشاركة لاءع فاثيولا الأغنام في الطائف، المملكة العربية السعودية

شريفة مصطفي محمد صبره

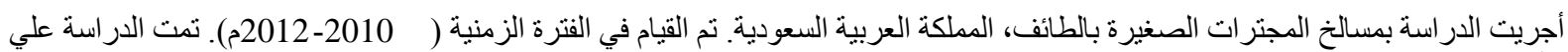

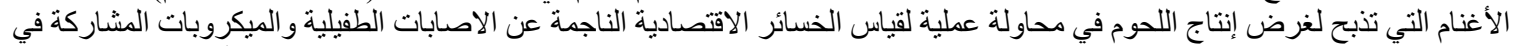

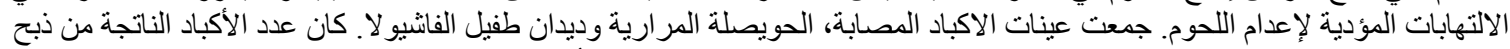

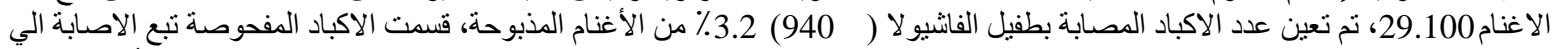

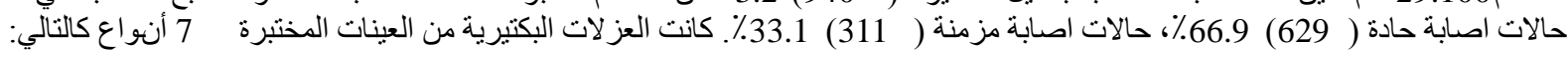

.Staph. spp., Strept. spp., E. coli., Proteus spp., Klebsiella spp., Clostridium perfringens and Clostridium novyi

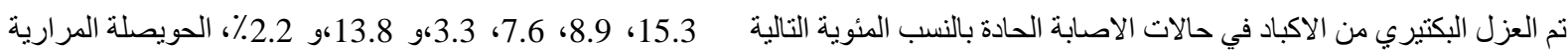

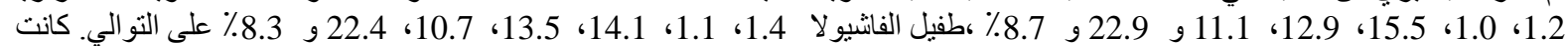

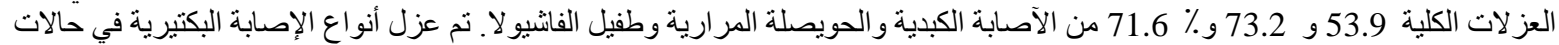

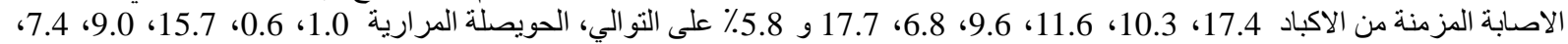

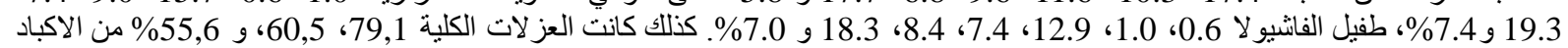

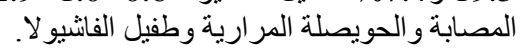

